Reaserch Article

\title{
Expression of Tenascin in the Uterosacral Ligament is Stronger in Women with Pelvic Organ Prolapse
}

\section{Tenascin pada Ligamentum Sakrouterina Diekspresikan lebih kuat pada Perempuan dengan Prolaps Organ Panggul}

\author{
Eny Lusiadewi, Trika Irianta, Efendi Lukas \\ Department of Obstetrics and Gynecology \\ Faculty of Medicine University of Hasanuddin/ \\ Dr. Wahidin Sudirohusodo Hospital \\ Makassar
}

\begin{abstract}
Objective: This study aimed to compare the expression of tenascin uterosacral ligament in women with and without pelvic organ prolapse (POP).

Methods: The research was carried out in Dr. Wahidin Sudirohusodo Hospital and other educational hospitals of obstetrics and gynecology division UNHAS Faculty of Medicine, which began on January 1st, 2011 until April 2012. This study assessed the expression of tenascin in 35 women with POP levels III and IV, and the controls were 35 women without POP. Tenascin expression was assessed by immunohistochemical examination using tenascin antibody staining (mouse monoclonal antibody Novacastra tenascin $\mathrm{C}$, code NCL-Tenas C). The research was carried out cross sectional. Sampling was done by consecutive sampling. Data processed by the chi-square. The significance level used was 0.05.
\end{abstract}

Results: The results showed that the characteristics of research subjects based on age, education, parity, labor history, history of big babies, not statistically significant. This indicates that the variable does not affect the calculation of the research data. While the characteristics of menopausal status and body mass index (BMI), from the analysis of risk factors for POP is associated significantly with a higher intensity of tenascin in post-menopausal status and BMI $>25$ (overweight) $(\mathrm{p}<0.05)$. Expression of tenascin in the sample are significantly more powerful, the weak expression $(8.6 \%)$, moderate $(40.0 \%)$, and strong $(51.4 \%)$ than without pelvic organ prolapsed. Expression of tenascin in the control, intensity tenascin weak (77.1\%), moderate (20.0\%), and strong (2.9\%).

Conclusion: Expression of tenascin uterosacral ligament was stronger in women with POP compared with a weaker expression of tenascin in women without POP.

[Indones J Obstet Gynecol 2013; 1-4: 199-203]

Keywords: pelvic organ prolapse, risk factors, tenascin

\begin{abstract}
Abstrak
Tujuan: Penelitian ini bertujuan membandingkan ekspresi tenascin ligamentum sakrouterina pada perempuan dengan dan tanpa prolaps organ panggul (POP).

Metode: Penelitian ini dilakukan di BLU RS Dr. Wahidin Sudirohusodo dan beberapa rumah sakit pendidikan bagian obstetri dan ginekologi FK-UNHAS yang dimulai pada tanggal 1 Januari 2011 sampai 1 April 2012. Penelitian ini menilai ekspresi tenascin pada 35 perempuan dengan POP tingkat III dan IV dan sebagai kontrol adalah 35 perempuan tanpa POP. Ekspresi tenascin dinilai dengan pemeriksaan imunohistokimia menggunakan pewarnaan antibodi tenascin (Novacastra mouse monoclonal antibody tenascin $C$, code NCL-Tenas C). Penelitian ini dilakukan secara cross sectional. Pengambilan sampel dilakukan secara consecutive sampling. Data diolah dengan chi-square. Tingkat signifikansi yang digunakan adalah 0,05.
\end{abstract}

Hasil: Hasil penelitian menunjukkan bahwa karakteristik subjek penelitian berdasarkan usia, pendidikan, paritas, riwayat persalinan, riwayat melahirkan bayi besar, tidak bermakna secara statistik. Hal ini menunjukkan bahwa variabel tersebut tidak mempengaruhi perhitungan data penelitian. Sedangkan karakteristik status menopause dan Indeks Masa Tubuh (IMT), dari analisis faktor risiko terjadinya POP yang dihubungkan dengan peningkatan intensitas tenascin tampak signifikan pada status post menopause dan IMT $>25$ (overweight) $(p<0,05)$. Ekspresi tenascin pada sampel secara signifikan lebih kuat ,yaitu ekspresi lemah (8,6\%), moderat $(40,0 \%)$, dan kuat $(51,4 \%)$ dibandingkan dengan tanpa prolaps organ panggul. Ekspresi tenascin pada kontrol dengan intensitas tenascin lemah $(77,1 \%)$, moderat (20,0\%), dan kuat $(2,9 \%)$.

Kesimpulan: Ekspresi tenascin ligamentum sakrouterina lebih kuat pada perempuan dengan POP dibandingkan dengan ekspresi tenascin yang lebih lemah pada perempuan tanpa POP.

[Maj Obstet Ginekol Indones 2013; 1-4:199-203]

Kata kunci: faktor risiko, prolaps organ panggul, tenascin

Correspondence: Eny Lusiadewi: Jln. Raya Faisal No. 14, Makassar. Telephone/mobile: 08123023806.

email: enylusiadewi18@yahoo.com

\section{INTRODUCTION}

Pelvic organ prolapse (POP) is a common health problem in women that could affect women of all age. It causes disturbance in daily activity, and its management often requires a high price. Eventhough it doesn't cause death but this condition could decrease an individual's quality of life, including problems in the urinary system, digestive system and also sexual disturbance. As the life expectancy and advanced age population increase, so will the prevalence of POP. ${ }^{1}$ 
DeLancey in 2005 stated that the disfunction of pelvic floor will affect 300,000 to 400,000 women in the USA each year. The condition could worsened until it requires an operation. The high prevalence of this condition shows the importance of changing the passive management of POP into a more active management. Primary prevention is very important because $30 \%$ of operation performed each year to repair thos condition is a reoperation. $^{2}$

The problem that once belonged only to developed country like the USA will slowly happen in developing countries such as Indonesia. The percentage of productive age population is quite high in Indonesia, and as time goes, the management of advanced age population will become a national problem. POP is a part of advanced age problem, thus it is a very important challenge to find out the cause of this condition.

Eventhough the incidence of POP is high, little is known about the underlying pathophysiology. Age, occupation, BMI, parity, history of childbirth method, the use of vacum and forceps in vaginal delivery, the children birthweight, history of operation, history of other diseases, menopausal status and hormon replacement therapy are some of the risk factors of POP.1,3-5

But, POP has also been found in women with no history of childbirth and no other risk factor. Thus it is thought that genetical predisposition plays a role in the occurence of this disease. The risk of having POP in women whose mother or sister had POP is 3.2. Meanwhile, in women whose mother or sister don't have the condition, the risk of POP is $2.4 .^{4}$

By understanding the etiology of pelvic floor disfunction, the therapy, and more importantly, the prevention strategy could be improved. The molecular basic of this condition is still not understood and the best choice for its management so far is still operation. ${ }^{6}$

One of the most important parts of the pelvic supporting systems is sacrouterine ligament. This ligament provides the major support for cervix and the upper vaginal wall. ${ }^{2}$ An in vitro study shows that the cervical part of sacrouterine ligament supported more than $17 \mathrm{kgs}$ of body weight before declining in function. ${ }^{7}$

The major elements of the tissue stability are quantity, ultrastructure and the organization of ex- tracellular matrix protein such as collagen and elastin (Ewies, 2003). The integrity of the connective tissue depends on lysyl oxidase (LOX), an extracellular enzyme connected with collagen and elastin. ${ }^{6}$

Goepel in 2007 studied the expression of elastin and tenascin in the sacrouterine ligament in a certain age group. This approach is deemed as not right. Ice berg phenomena will cause the patients in the productive age group to go undetected. This could be harmful to patients as it makes early prevention and intervention to be impossible. ${ }^{8}$

The theory of the abnormalities of connective tissue structure and its repair mechanism as a predisposing factor for POP is the basic of this study. This study has never been performed in Makassar, thus it is thought to be important to perform this study. The result of this study is expected to show that the expression of tenascin in women with POP could contribute into the understanding of pelvic organ prolapse.

\section{METHOD}

This study was conducted from January 2011 to April 2012 in several teaching hospitals affiliated with the Department of Obstetrics and Gynecology Faculty of Medicine, University of Hasanuddin. The tissue examination was performed in the Pathology Anatomy Laboratorium of Faculty of Medicine University of Hasanuddin. This was a cross-sectional study, performed in order to know the difference of tenascin expression in the sacrouterine ligament of women with pelvic organ prolapse and normal women.

The subject of this study was women with severe degree of POP (grade III and IV) who would have an operation and women with benign gynecologic condition who were willing to participate. We explained the objective and method of the study to the subjects and obtained their signature in the consent form. The results of history taking, physical examination and other examination were recorded in a questionnaire.

The tissue sample were fixated with $10 \%$ formalin buffer solution. An immunohistochemical examination, with indirect immunoenzyme technique with labeled streptovidin complex, was then performed in the laboratorium. The interpretation of tenascin expression was obtained from the histopathological examination of the sample. 
The data was then analyzed with chi-square, Fisher exact, Mann Whitney, and non parametric test. All data was presented in the form of table or narration. We analyzed the data with SPSS for window versi 17.

\section{RESULT}

In this study, we found that except for menopausal status, all risk factors, including age, education, history of infant weighted more than 3500 gram, parity, and BMI showed no significant difference between the group with prolapse and the group without prolapse. The characteristic of subjects in both group are described in Table 1 below.

Tabel 1. The Comparison of Subject's Characteristics in both Groups

\begin{tabular}{|c|c|c|c|c|c|}
\hline \multirow{2}{*}{ Characteristics } & \multicolumn{2}{|c|}{ With Prolapse } & \multicolumn{2}{|c|}{ Without Prolapse } & \multirow{2}{*}{$\underset{\text { Value }}{\mathbf{p}}$} \\
\hline & $\mathbf{n}$ & $\%$ & $\mathbf{n}$ & $\%$ & \\
\hline \multicolumn{6}{|l|}{ Age (Years) } \\
\hline$\leq 45$ & 2 & 5.7 & 2 & 5.7 & 0.641 \\
\hline$>45$ & 33 & 94.3 & 33 & 94.3 & \\
\hline \multicolumn{6}{|l|}{ Education (Years) } \\
\hline$\leq 9$ & 26 & 74.3 & 26 & 74.3 & 0.767 \\
\hline$>9$ & 9 & 25.7 & 9 & 25.7 & \\
\hline \multicolumn{6}{|l|}{ Parity } \\
\hline 0 & 2 & 5.7 & 4 & 11 & 0.072 \\
\hline $1-2$ & 5 & 14.3 & 12 & 34.3 & \\
\hline$>3$ & 28 & 80.0 & 19 & 54.3 & \\
\hline \multicolumn{6}{|l|}{ Delivery Method } \\
\hline Nullipara & 2 & 5.7 & 4 & 11.4 & 0.367 \\
\hline Normal Delivery & 32 & 29.4 & 27 & 77.1 & \\
\hline Vacum & 1 & 2.9 & 0 & 0 & \\
\hline Sectio Caesarean & 0 & 0 & 4 & 11.4 & \\
\hline \multicolumn{6}{|c|}{ History of infant weighted > 3500 gram } \\
\hline Yes & 28 & 80 & 30 & 85.7 & 0.376 \\
\hline No & 7 & 20 & 5 & 14.3 & \\
\hline \multicolumn{6}{|l|}{ Menopausal Status } \\
\hline Premenopause & 4 & 11.4 & 21 & 60 & 0.003 \\
\hline Menopause & 31 & 88.6 & 14 & 40 & \\
\hline \multicolumn{6}{|l|}{ BMI } \\
\hline Normal 18.5-24.99 & 11 & 3.4 & 22 & 62.9 & 0.008 \\
\hline Obese $>25.0$ & 24 & 68.6 & 13 & 37.1 & \\
\hline
\end{tabular}

Chi-square test, Fisher Exact test, Mann-Whitney
Tabel 2. Tenascin Expression in the Sacrouterine Ligament of Subjects with POP and without POP

\begin{tabular}{lccc}
\hline \hline \multirow{2}{*}{$\begin{array}{c}\text { Tenascin } \\
\text { Expression }\end{array}$} & \multicolumn{2}{c}{ Group } & Total \\
\cline { 2 - 3 } & POP & Without POP & \\
\hline Mild & 3 & 27 & 30 \\
& $8.6 \%$ & $77.1 \%$ & $42.9 \%$ \\
Moderate & 14 & 7 & 21 \\
& $40.0 \%$ & $20.0 \%$ & $30.0 \%$ \\
Strong & 18 & 1 & 19 \\
& $51.4 \%$ & $2.9 \%$ & $27.1 \%$ \\
\hline \multirow{2}{*}{ Total } & 35 & 35 & 70 \\
& $100 \%$ & $100 \%$ & $100 \%$ \\
\hline \hline
\end{tabular}

$p=0,000(p<0,05)$

Table 2 shows the difference of tenascin expression in the case and control group. In the case group, 18 subjects $(51.4 \%)$ showed a strong expression of tenascin, while in the control group, only 1 subject had a strong expression of tenascin. Mann-Whitney test was performed to compare both groups. The result shows that tenascin expression is stronger in the subjects with POP.

Table 3. Risk Factor Analysis of Pelvic Organ Prolapse

\begin{tabular}{|c|c|c|c|c|c|c|c|}
\hline \multirow{3}{*}{ Risk Factor } & \multicolumn{6}{|c|}{ Tenascin Expression } & \multirow{3}{*}{$\mathbf{p}$} \\
\hline & \multicolumn{3}{|c|}{ POP } & \multicolumn{3}{|c|}{ Without POP } & \\
\hline & Weak & Moderate & Strong & Weak & Moderate & Strong & \\
\hline Age (Years) & & & & & & & 0.301 \\
\hline $\begin{array}{l}\leq 45 \\
>45\end{array}$ & $\begin{array}{r}1 \\
25\end{array}$ & $\begin{array}{l}1 \\
7\end{array}$ & $\begin{array}{l}0 \\
1\end{array}$ & $\begin{array}{l}0 \\
5\end{array}$ & $\begin{array}{r}0 \\
17\end{array}$ & $\begin{array}{r}2 \\
11\end{array}$ & \\
\hline Parity & & & & & & & 0.224 \\
\hline $\begin{array}{l}0 \\
1-2 \\
>3\end{array}$ & $\begin{array}{r}2 \\
3 \\
21\end{array}$ & $\begin{array}{l}0 \\
2 \\
6\end{array}$ & $\begin{array}{l}0 \\
0 \\
1\end{array}$ & $\begin{array}{l}1 \\
2 \\
2\end{array}$ & $\begin{array}{r}1 \\
5 \\
11\end{array}$ & $\begin{array}{l}2 \\
5 \\
6\end{array}$ & \\
\hline Delivery History & & & & & & & 0.459 \\
\hline $\begin{array}{l}\text { Nullipara } \\
\text { Normal } \\
\text { Vacuum } \\
\text { SC }\end{array}$ & $\begin{array}{r}2 \\
23 \\
1 \\
0\end{array}$ & $\begin{array}{l}0 \\
8 \\
0 \\
0\end{array}$ & $\begin{array}{l}0 \\
1 \\
0 \\
0\end{array}$ & $\begin{array}{l}1 \\
3 \\
0 \\
1\end{array}$ & $\begin{array}{r}1 \\
15 \\
0 \\
1\end{array}$ & $\begin{array}{l}2 \\
9 \\
0 \\
2\end{array}$ & \\
\hline Children Birthweigh & & & & & & & 0.655 \\
\hline $\begin{array}{l}\leq 3500 \text { gram } \\
>3500 \text { gram }\end{array}$ & $\begin{array}{r}22 \\
4\end{array}$ & $\begin{array}{l}5 \\
3\end{array}$ & $\begin{array}{l}1 \\
0\end{array}$ & $\begin{array}{l}4 \\
1\end{array}$ & $\begin{array}{r}14 \\
3\end{array}$ & $\begin{array}{r}12 \\
1\end{array}$ & \\
\hline Menopausal Status & & & & & & & 0.009 \\
\hline $\begin{array}{l}\text { Premenopause } \\
\text { Menopause }\end{array}$ & $\begin{array}{r}2 \\
24\end{array}$ & $\begin{array}{l}2 \\
6\end{array}$ & $\begin{array}{l}0 \\
1\end{array}$ & $\begin{array}{l}4 \\
1\end{array}$ & $\begin{array}{l}9 \\
8\end{array}$ & $\begin{array}{l}8 \\
5\end{array}$ & \\
\hline BMI & & & & & & & 0.013 \\
\hline $\begin{array}{l}\text { Normal } 18.5-24.99 \\
\text { Obesity }>25.0\end{array}$ & $\begin{array}{r}9 \\
17\end{array}$ & $\begin{array}{l}2 \\
6\end{array}$ & $\begin{array}{l}0 \\
1\end{array}$ & $\begin{array}{l}2 \\
3\end{array}$ & $\begin{array}{l}9 \\
8\end{array}$ & $\begin{array}{r}11 \\
2\end{array}$ & \\
\hline
\end{tabular}

Table 3 shows the result of risk factor analysis. Menopausal status and BMI were found to be a significant risk factor in the occurence of POP. Women with BMI over 25 , or overweight, have a higher risk 
of developing POP. BMI of over 25 was also related to the increasing intensity of tenascin expression.

\section{DISCUSSION}

Most subjects in the case group of this study were over 45 years old (93.4\%). This cut off was taken because women aged 45 years old were categorized as in the premenopausal stage. This finding is similar with the finding of the study by Swift et al that study found that POP grade I and II were mostly found in younger women. ${ }^{9,10}$ Meanwhile, POP grade II and IV were mostly found in women older than 40 years old and the number increased to $21 \%$ in women older than 70 years old.

Most subjects with POP had a history of delivery more than 3 times (80\%). This finding is consistent with the finding of Chiaffarino et al. The study found that women with high parity tend to have higher risks to develop POP(OR 2.6). ${ }^{4}$ This supports the hypothesis that pervaginam delivery cause a significant change in the supporting tissue of the pelvic floor and damage to the pudendal nerve. Vaginal delivery also cause a loosening of the ligament structure in the pelvic area.

Most subjects with POP in this study had a history of vaginal delivery (91.4\%). This is consistent with the study by Lukacz et al, which found that c-section had a protective effect in development of POP, and urine incontinency. ${ }^{12}$ The incidence of POP in nullipara, women with history of c-section and women with the history of vaginal delivery were $4 \%, 4 \%$, dan $8 \%$ respectively.

Most subjects with POP had already had menopause $(88.6 \%)$. This is consistent with the hypothesis stating that decreasing level of estrogen in menopausal women is also a secondary factor of POP. Chen et al found a decreasing level of estrogen receptor in the vaginal wall and sacrouterine ligament in postmenopausal women. ${ }^{12}$

Most subjects with POP (68.6\%) were overweight (IMT > 25). Hendrix et al also conclude that obesity had a great influence over the pelvic floor function. Women's Health Initiative (WHI) found that in women with BMI of $25-30 \mathrm{~kg} / \mathrm{m}^{2}, 31 \%$ had prolapsed uterus, $38 \%$ had rectocele dan $39 \%$ had cystocele. This percentage continued to increase in the higher BMI group. ${ }^{13}$

In this study, the expression of tenascin in the sacrouterine ligament was found to be stronger in subjects with POP. This data provides a theory that tenascin plays an important role in the pathophysiology of POP. But unfortunately the factors influencing the structure of tenascin are not known yet. ${ }^{8}$ Connective tissue abnormality in the ligament could cause a disfunction in the pelvic floor. Elastin expression in the anterior vagina wall is known to decrease in women with POP. This shows that decreasing elasticity of the ligament contribute to the diminishing function of the ligament as a structural support in women with POP.

The important part of this structural support is sacrouterine ligament. This ligament provides a major support for cervix and upper vagina wall. ${ }^{2}$ An in vitro study shows that the cervical part of sacrouterine ligament supported more than $17 \mathrm{kgs}$ of body weight before declining in function. ${ }^{7}$

Risk factor analysis in this study revealed that menopause status and BMI are significant as the risk factor of POP development. In menopause, estrogen level will decrease, causing tissue decompensation. ${ }^{12}$

Eventhough age, parity, delivery method and the baby's birthweight were not statistically significant, but the result showed a relationship of those factors with the increasing expression of tenascin.

Levator ani muscle and ligament works together to support the organs in the pelvic. Delancey pictured this structure as "a ship floating on the water with its two sides fastened to the dock by ropes". The ship represents pelvic organ, the water represents levator ani muscle, the ropes represent endopelvic fascia and connective tissue. If the water is reduced, the ship will descend and if the load of the ship is too heavy, the ropes could be loosened or even break.

If levator ani muscle is analogized as a support, if the muscle is weakened, the supporting function will be diverted to the connective tissue to maintain the position of pelvic organ. But if the load exceeds a certain limit, the connective tissue will ceased to function. This event will be followed by a perlvic organ prolapse and possibly urinary incontinence. $^{14}$

\section{CONCLUSION}

Tenascin expression in sacrouterine ligament is stronger in women with severe pelvic organ prolapse. BMI and menopause status is found to have 
a significant relationship with the increasing tenascin expression. Further study with larger sample or on molecular level is required to understand the role of tenascin in the development of uterine prolapse.

\section{REFERENCES}

1. Patel PD, Amrute KV, Badlani GH. Pelvic organ prolapse and stress urinary incontinence : A review of etiological factors. Indian J Urol 2007.

2. De Lancey JOL. The hidden epidemic of pelvic floor dysfunction : Achievable goals for improved prevention and treatment. Am J Obstet Gynecol 2005; 192: 5

3. Barsoom RS. Uterine Prolapse. Available at:http://www. emedicine.com. Last updated Jun $12^{\text {th }} 2009$

4. Chiaffarino F. Reproductive factors, family history, occupation and risk of urogenital prolapse. Eur Obstet Gynecol J 1999; 82: 63-7

5. Swift S, Tate SB. Correlation of symptoms with degree of pelvic organ support in a general population of women: What is pelvic organ prolapse? Am J Obstet Gynecol 2003; 189: 2

6. Klutke J, Qing Ji. Decreased endopelvic fascia elastin content in uterine prolapse. Acta Obstet et Gynecol 2008; 87:111-5

7. Ewies $\mathrm{AA}, \mathrm{Al}$-azzawi $\mathrm{F}$ et al. Changes in extracellular matrix proteins in the cardinal ligaments of post-menopausal women with or without prolapse : a computerized immunohistomorphometric analysis. Hum Reprod 2003; 18: 10

8. Goepel C. Differential elastin and tenascin immunolabeling in the uterosacral ligaments in postmenopausal women with and without pelvic organ prolapse. Acta histochemica 2008. 110: 204-9

9. Swift S, Tate SB. Correlation of symptoms with degree of pelvic organ support in a general population of women: What is pelvic organ prolapse? Am J Obstet Gynecol 2003; 189: 2

10. Swift S, Woodman P, O'Boyle AL. Pelvic Organ Support Studdy (POSST): The distribution, clinical definition, and epidemiologic condition of pelvic organ support defects. Am J Obstet Gynecol 2005; 192: 3

11. Lukacz ES, Lawrence JM, Contreras R, Nager CW, Luber KM. Parity, mode of delivery and pelvic floor disorders. Obstet Gynecol 2006; 107: 1253-60

12. Chen GD. Pelvic floor dysfunction in aging women. Taiwan J Obstet Gynecol 2007; 46: 374-8

13. Hendrix SL, Clark A, Nygaard I, Aragaki A, Barnabei V, McTiernan. Pelvic organ prolapse in the women's health initiative. Gravity and gravidity. Am J Obstet Gynecol 2002; 195:23-8

14. Valaitis SR. Anterior Compartment Prolapse, Urinary Incontinence, and the Effects of Anterior Colporrhaphy and Paravaginal Repair. In: Lentz GM, ed. Urogynecology. London: Arnold 2000: 118-34 